\title{
The current status of mapping karst areas and availability of public sinkhole-risk resources in karst terrains of the United States
}

\author{
Eve L. Kuniansky ${ }^{1}$ - David J. Weary ${ }^{2}$. James E. Kaufmann ${ }^{3}$
}

Received: 3 May 2015 / Accepted: 26 October 2015 / Published online: 25 November 2015

(C) The Author(s) 2015. This article is published with open access at Springerlink.com

\begin{abstract}
Subsidence from sinkhole collapse is a common occurrence in areas underlain by water-soluble rocks such as carbonate and evaporite rocks, typical of karst terrain. Almost all 50 States within the United States (excluding Delaware and Rhode Island) have karst areas, with sinkhole damage highest in Florida, Texas, Alabama, Missouri, Kentucky, Tennessee, and Pennsylvania. A conservative estimate of losses to all types of ground subsidence was $\$ 125$ million per year in 1997. This estimate may now be low, as review of cost reports from the last 15 years indicates that the cost of karst collapses in the United States averages more than $\$ 300$ million per year. Knowing when a catastrophic event will occur is not possible; however, understanding where such occurrences are likely is possible. The US Geological Survey has developed and maintains national-scale maps of karst areas and areas prone to sinkhole formation. Several States provide additional resources for their citizens; Alabama, Colorado, Florida, Indiana, Iowa, Kentucky, Minnesota, Missouri, Ohio, and Pennsylvania maintain databases of sinkholes or karst features, with Florida, Kentucky, Missouri, and Ohio providing sinkhole reporting mechanisms for the public.
\end{abstract}

Published in the theme issue "Land Subsidence Processes"

Eve L. Kuniansky

elkunian@usgs.gov

1 US Geological Survey, 1770 Corporate Drive, Suite 500, Norcross, GA 30093, USA

2 US Geological Survey, MS926A National Center, 12201 Sunrise Valley Drive, Reston, VA 20192, USA

3 US Geological Survey, Earth Resources Observation and Science Center, 19986 State Route F, Saint James, MO 65559, USA
Keywords Subsidence $\cdot$ Geohazards $\cdot$ Sinkholes $\cdot$ Karst . United States

\section{Introduction}

Subsidence from sinkhole collapse is a common occurrence in areas underlain by water-soluble rocks such as carbonate and evaporite rocks, typical of karst terrain, a landscape with features such as sinkholes, sinking streams, and springs, which reflect the presence of subsurface voids or caves (Ford and Williams 2007). The term "karst" has been widened to include both features that reflect surficial dissolution processes (epigenic karst), and more recently, features that reflect dissolution processes at depth (hypogenic karst); both result in subsurface voids with the potential for subsidence, sudden sinkhole collapse, or cave development (Palmer 1991, 2000; Klimchouk 2007; Palmer and Palmer 2009, 2011).

There are different classifications of sinkhole types. Waltham et al. (2005) defined six classes: solution, collapse, caprock, dropout, suffosion, and buried (Table 1; Fig. 1a). An illustration from a poster from the Florida Geological Survey shows slightly different sinkhole types (Rupert and Spencer 2004) common in Florida (Fig. 1b). Robertson and Orndorff (2013) lumped sinkholes into two major types: cover-collapse and cover subsidence; cover-collapse includes sinkholes that form over a period of hours or days resulting in often catastrophic damage, and cover-subsidence sinkholes form slowly over time resulting in the gradual subsidence of the ground. Tihansky (1999) categorized the three main sinkhole types in Florida (dissolution, cover-subsidence and cover-collapse) that develop from the processes of dissolution and suffosion, noting that some sinkholes are a combination of types and can form in different phases. All sinkholes in karst require dissolution of soluble rocks. Suffosion is the process where 
surficial unconsolidated sediments infill voids below and can occur catastrophically (cover-collapse sinkhole) or gradually (cover-subsidence sinkhole) over time. It is the rapidly occurring dropout or cover-collapse sinkhole that is most dangerous.

Studies in Florida indicate an increase in the frequency of sinkhole formation corresponding to the increase in groundwater development, drilling, surface loading, urban expansion into previously undeveloped sinkhole-prone areas, and drought-precipitation extremes (Wilson and Shock 1996; Tihansky 1999). Both drought and increasing groundwater development lower groundwater levels resulting in increased effective stresses on the supporting rock and drainage of water-filled submerged caverns, all of which can result in increases in sinkhole formation. Additionally, precipitation extremes, especially following a period of drought or immediately following flooding, correlate with an increase in karst sinkhole formation. Urban expansion into karst areas often results in the discovery of sinkholes and other karst features. Additionally, construction and well drilling can change groundwater levels and recharge patterns, both of which can induce sinkholes in karst areas. There is ongoing confusion among non-geologists as to what constitutes a sinkhole. The news media, utility workers, and highway engineers often refer to any localized ground collapse as a 'sinkhole'. Often these collapses are caused by leaking water, sewer, or drainage pipes and are not genetically related to karst sinkholes. In some cases, however, these artificial 'sinkholes' can occur over karst terrains, or in conjunction with karst processes, making their true causation ambiguous.

The destruction of life and property is an obvious hazard from the sudden collapse and subsidence when a sinkhole forms beneath structures. Almost all 50 states within the United States (US) have karst areas (exceptions are Delaware and Rhode Island), with the greatest amount of karst sinkhole damage occurring in Florida, Texas, Alabama, Missouri, Kentucky, Tennessee, and Pennsylvania (in decreasing order of damage). Florida is at the greatest risk and has the most frequent occurrences of sinkholes as the entire state is underlain by surficial or fairly shallow carbonate rocks over 1 , $000 \mathrm{~m}$ thick (Williams and Kuniansky 2015). During periods of surface exposure, precipitation of weak carbonic acid rainfall can aggressively dissolve carbonate rocks, thus there is both paleokarst and current karst development. The Federal Emergency Management Agency (FEMA 1997) conservatively estimated losses attributed to all types of ground subsidence to be at least $\$ 125$ million per year in the US. A review of publically available cost reports from the past 15 years indicates that the cost of karst collapses in the US averages at least $\$ 300$ million per year. Much of the cost is incurred in Florida where insurance sources reported more than \$84 million in sinkhole losses plus adjustment expenses in 2009. The Florida Office of Insurance Regulation (2010) reported that 

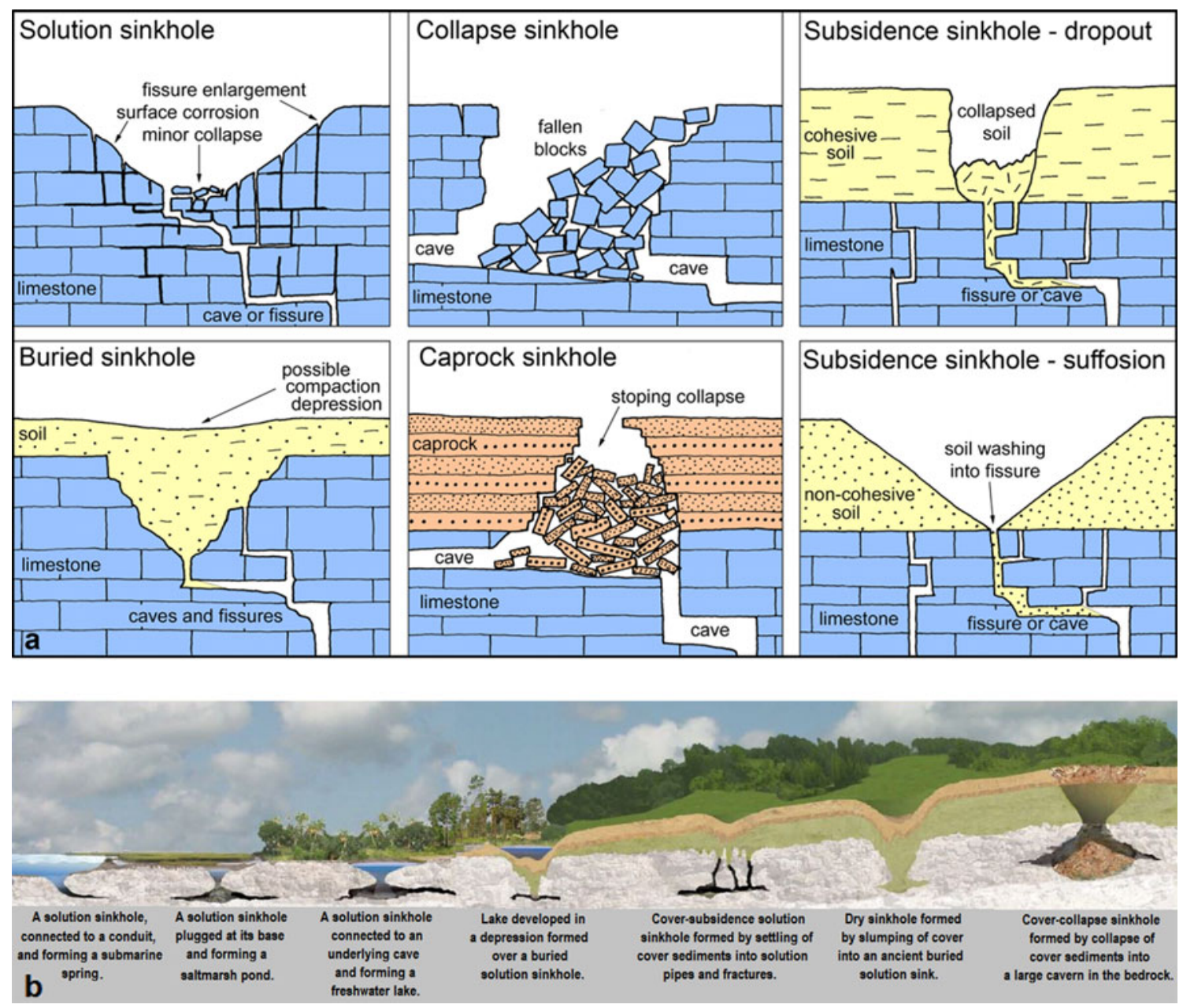

Fig. 1 a Cross-sectional diagrams for six types of sinkholes defined by Waltham et al. (2005) described in Table 1 (illustration provided by Tony Waltham, written communication, 2015) and b illustration of sinkholes in Florida (modified from Rupert and Spencer 2004)

insurers had received 24,671 claims for sinkhole damage in Florida between 2006 and 2010 totaling \$1.4 billion, an average of $\$ 280$ million per year for those 5 years. Cost per year in Florida is on an increasing trend with total sinkhole losses for closed and open claims combined increasing from $\$ 209$ million in 2006 to \$406 million in 2009 (The Florida Senate 2010).

The depositional environments, diagenetic processes, postdepositional tectonic events, and geochemical weathering processes that form karst aquifers and landforms are varied and complex, and involve biological, chemical, and physical changes. The complex hydrogeologic systems in karst terrain represent challenging and unique conditions for engineers and scientists attempting to mitigate hazards posed by sinkholes and subsidence. Waltham et al. (2005) published a textbook on the engineering issues related to subsidence and sinkholes in karst and cavernous rocks. The Florida Geological Survey published a report on how to evaluate sinkholes (Schmidt 2005). The states with the greatest sinkhole hazard risk in the aforementioned provide useful information on the science of sinkholes on their websites.
In the US, the unique challenges posed by sinkholes resulted in the late Barry Beck developing a series of multidisciplinary conferences entitled "Sinkholes and the Engineering and Environmental Impacts of Karst." There have been 13 conferences convened since 1984 (Beck 1984, 1989, 1993, 2003, 2005; Beck and Wilson 1987; Beck and Pearson 1995; Beck and Stephenson 1997; Beck et al. 1999; Beck and Herring 2001; Land et al. 2013; Yuhr et al. 2008, 2011) with conferences held every 2 years. The environmental problems related to karst sinkholes are substantial, owing to the increased vulnerability of groundwater from rapid infiltration of surface water through sinkholes. The transfer of anthropogenic contaminants resulting in water-quality degradation near sinkholes is well understood, such that aquifer vulnerability assessments in karst terrain generally include geospatial analysis of sinkhole distribution (Arthur et al. 2007; Lindsey et al. 2010). Numerous publications are devoted to understanding speleogenesis, geomorphology, and hydrogeology of karst landscape and aquifer systems (Sweeting 1973; Jakucs 1977; Bögli 1980; Jennings 1985; Trudgill 1985; Watson and White 1985; Dreybrodt 
1988; White 1988; Ford and Williams 1989; Lowe 1992; Shaw 1992; Klimchouk et al. 2000).

Numerous government agencies in the US, both federal and state, provide detailed information on the location of karst areas and areas prone to sinkhole development. While this information does not make it possible to know when a catastrophic sinkhole event will occur, it does provide critical spatial detail on where sinkhole development has occurred and is likely to occur in the future. The purpose of this paper is to describe the current status of mapping karst areas, but focuses on sinkhole risk areas in the US and the availability of associated public resources such as sinkhole mapping efforts and databases.

\section{National mapping of karst and potential sinkhole risk areas}

Maps of karst areas and their associated engineering aspects have been developed and published at the scale of the entire United States (Davies and LeGrand 1972; Davies et al. 1984). The work of Davies et al. (1984) was published as a digitally available geospatial dataset by Tobin and Weary (2004). In 2014, the US Geological Survey (USGS) provided a digital version of updated maps showing areas of soluble rocks based primarily on updated state geologic maps of rock units containing substantial amounts of carbonate or evaporite minerals (Weary and Doctor 2014). The digital map data were compiled from a series of integrated geologic map databases for the US and produced by the USGS Mineral Resources Program (USGS 2014). The main source of original data for the Minerals Resources Program is state geologic maps at scales ranging from 1:250,000 to $1: 1,000,000$. Use of the USGS digital geologic data provided a consistent data structure within which a derivative database of areas having potential for karst could be constructed. Edits, deletions, and additions to this database were made based on (1) comparison to other published karst maps (principally Davies et al. 1984; Veni 2002); (2) comments and contributions by other cave and karst researchers having local knowledge of particular areas, and assisted by the comprehensive compilation in Palmer and Palmer (2009); and (3) the professional judgment of the authors (Weary and Doctor 2014). Further characterization of the karst areas was also accomplished via overlay analyses with other data, including distribution of glacially derived sediments (Soller et al. 2012) and Level III Ecoregions (US Environmental Protection Agency 2013). The purpose of the USGS mapping is to delineate the distribution of karst, potential karst, and pseudokarst (non-dissolving rock terrain with sub-surface drainage such as volcanic terrain with lava tubes) areas of the US. Because the data are compiled from a variety of sources with differing scales, various geologic datasets, spatial errors and location inconsistencies, the resulting mapping should not be used for site-specific application (Weary and Doctor 2014). Figures 2 and 3 show the national-scale mapping of karst areas of the United States.

Areas of outcrop and near-surface evaporite rocks and the extent of subsurface evaporite basins are mapped for the conterminous US (Weary and Doctor 2014). "The evaporite basins contain soluble rocks buried to depths of as much as 7 , $000 \mathrm{ft}$, but generally much less. Because of the physical properties and very high solubility of evaporite rocks, human activities such as fluid injection, or the occurrence of leakage from well casings, can induce the formation of large solution voids. Collapses of these voids are known to propagate up to the surface from depths of more than 1,000 ft." (Weary and Doctor 2014). The extent of the evaporite basins is derived in part from information provided in Dunrud and Nevins (1981) and Johnson (2007).

The combination of Figs. 2 and 4 provides the best delineation of areas in the contiguous US where sinkholes and subsidence from dissolution of rocks are possible. However, these maps cannot replace local and state agency data on sinkhole occurrence. In the Florida peninsula, deeply buried evaporite rocks are present (Fig. 4), but sinkhole formation at land surface has no known relationship with these deeply buried evaporite deposits. The newer digital maps published by the USGS (Weary and Doctor 2014) provide a valuable resource for the public and are largely a result of the USGS National Cooperative Geologic Mapping Program, which relies on federal, state, and university partners to deliver these digital geologic map products (USGS 2015a).

Aside from distributing maps of karst and evaporite areas, the USGS has assisted news agencies with information about sinkholes and developed educational materials about karst in general and sinkholes in particular. Shortly after the catastrophic sinkhole collapse of February 28, 2013, in Florida that resulted in the death of one man, Robertson and Orndorff (2013) posted an article online on March 11, 2013, describing the occurrence and causes of sinkholes. The USGS developed educational training materials on karst topography for use by teachers for grades 5-12 (Alpha et al. 1997). Additionally, the USGS Water Science School website has a page dedicated to sinkholes and is available online (USGS 2015b).

\section{State resources}

All 50 states have contributed to geologic mapping in the US through the National Cooperative Geologic Mapping Program, which is the "primary source of funds for the production of geologic maps in the United States and provides accurate geologic maps and three-dimensional framework models that help to sustain and improve the quality of life and economic vitality of the Nation and to mitigate natural 


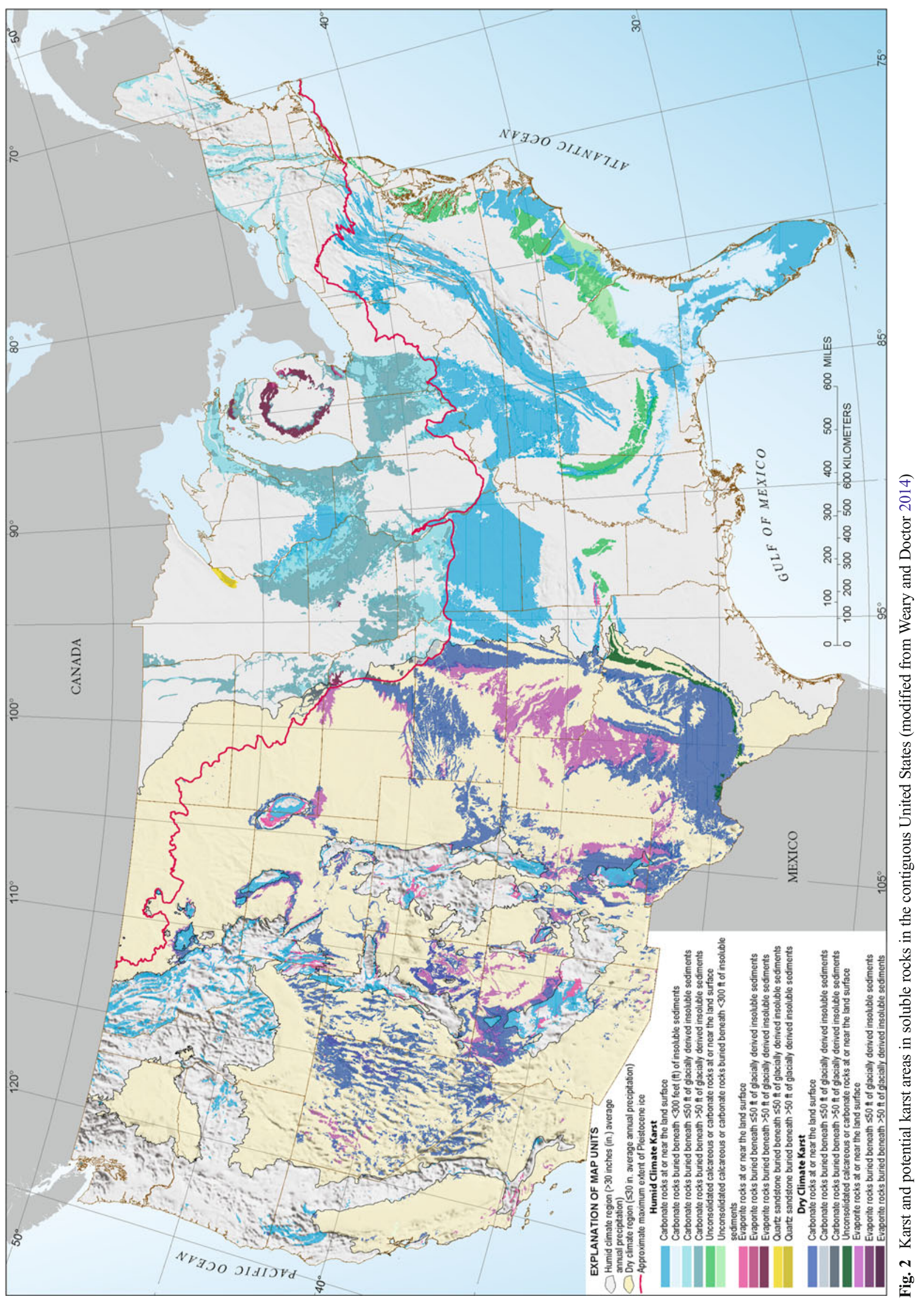




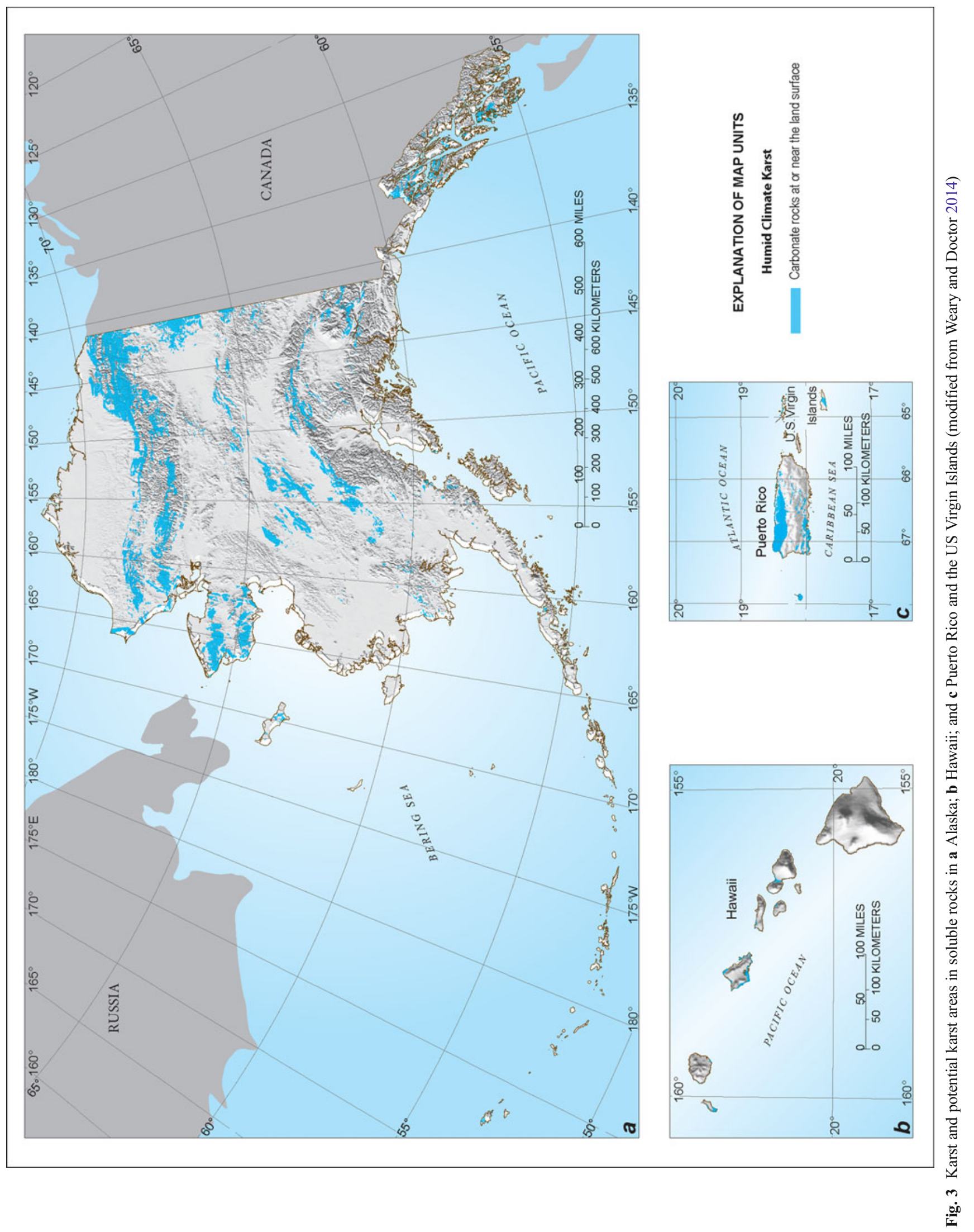




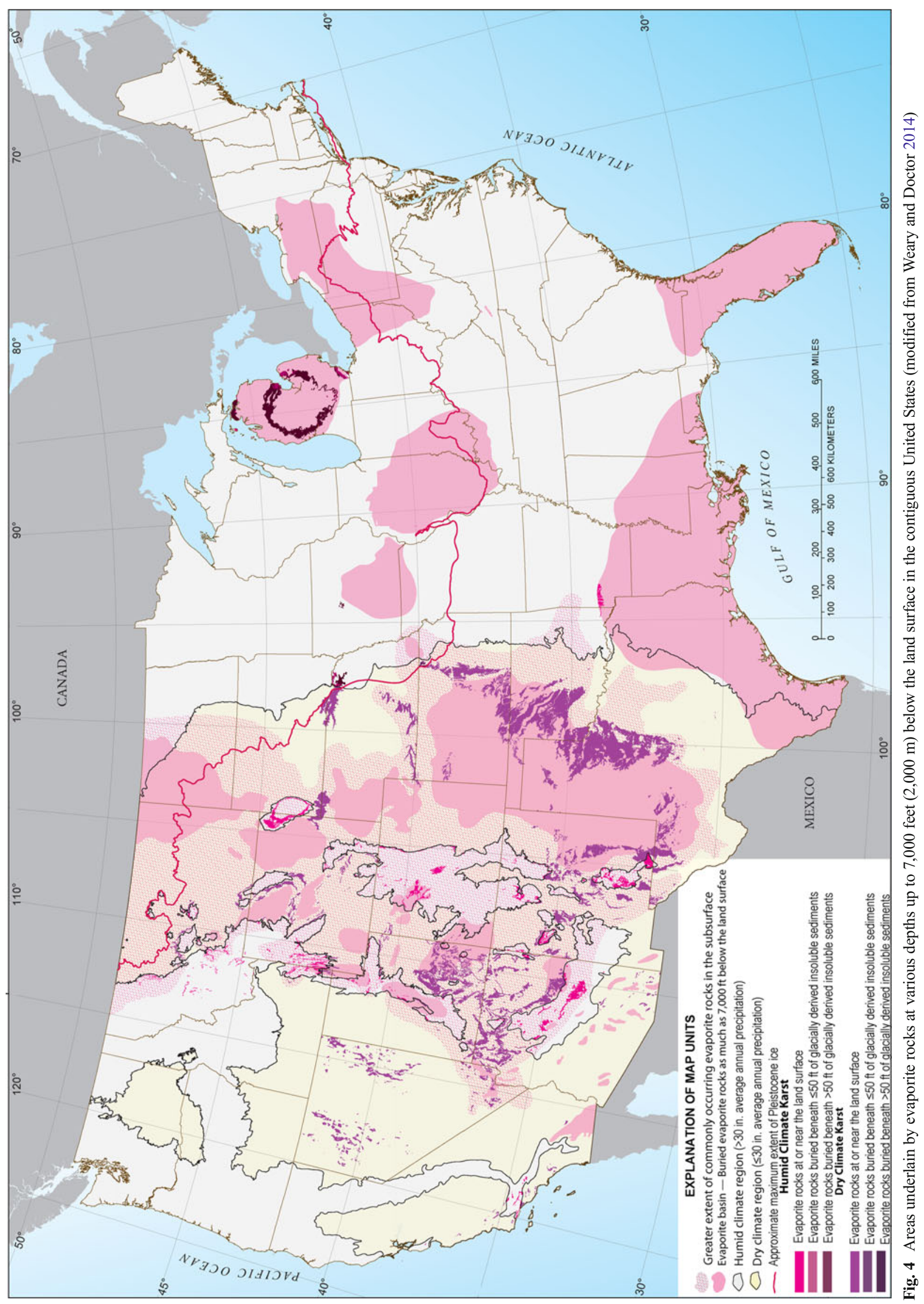


hazards (USGS 2015a)". Many of these maps fed into the derivative national-scale mapping of karst discussed in the previous section. While all states have mapped carbonate and evaporite rocks, not all have developed sinkhole risk maps or maintain databases of sinkholes. The National Cave and Karst Research Institute (NCKRI) maintains a website that has links to each state agency involved in geologic mapping and links to the state webpages for geologic hazards, karst, or sinkholes and subsidence, if available (NCKRI 2015). Alabama, Arizona, Florida, Illinois, Indiana, Iowa, Kentucky, Maryland, Minnesota, Missouri, Ohio, Pennsylvania, Texas, Virginia, West Virginia, and Wisconsin have links from the NCKRI website to either geologic hazards, sinkholes, or karst mapping.

Alabama, Florida, Kentucky, Minnesota, Missouri, and Pennsylvania maintain state databases of sinkholes or karst features, with Florida, Kentucky, Missouri and Ohio also maintaining sinkhole-reporting mechanisms for the public. Maryland provides information about karst sinkholes through the Maryland Geological Survey website. Locating publicly available resources for each state is not straight forward, and was accomplished from knowledge of the authors and searches of the Internet from the US Government's open data web service (USA 2015), searches of the USGS ScienceBaseCatalog (USGS 2015c), and searches using web searching tools such as Google and Bing with terms such as karst and sinkhole. Additionally the links from the NCKRI website mentioned in the previous were checked for sinkhole resources in each state.

Florida has delineated areas of different sinkhole types and risks, and Alabama has developed a sinkhole density map. In advising the public on steps to take upon discovering a sinkhole, most states provide guidance similar to that provided in Alabama: (1) place a barrier around the sinkhole to warn people of the sinkhole; (2) contact your homeowner's insurance company; (3) depending on how close the sinkhole is to a building, consider contacting a geologist, engineer, or foundation specialist; (4) if the sinkhole is affecting public property or safety (parks, sidewalks, water or sewer drainage), consider contacting city or county department of public works or engineering department; (5) if the sinkhole is affecting a public road or highway, contact the Department of Transportation (modified from website Geological Survey of Alabama (2015).

More details about public information available on websites from the states of Alabama, Colorado, Florida, Illinois, Indiana, Iowa, Kentucky, Maryland, Minnesota, Missouri, Ohio, Pennsylvania, Tennessee, and Texas follow in the subsequent sections. Note that not all state resources are provided; however, the full range of types of available public information from states is provided, such as Florida, with extensive information provided on karst features and sinkholereporting mechanisms for the public, to Maryland, which provides a map of karst area and information on who to contact if a sinkhole is suspected. Additionally, the sources of publicly available information at the state level vary from caving societies to state geological surveys within universities, to state geological surveys within state governments or departments of natural resources.

The Geologic Survey of Alabama maintains a website on sinkholes and karst as part of their Geological Hazards Program (Geological Survey of Alabama 2015), which has a link to the data shown on a map of naturally occurring sinkholes (Ebersole and Tavis 2010).

Colorado's Natural Hazards Mitigation Plan includes hazards due to subsidence attributable to natural karst processes and related to mining activities (Colorado Division of Homeland Security and Emergency Management 2013). As part of the hazard plan, the Colorado Geological Survey has produced a map of evaporite karst subsidence hazards (White 2012). The map includes downloadable geographic information system (GIS) files.

The Florida Geological Survey (FGS) has a website devoted to providing an understanding of the occurrence of sinkholes (FGS 2012a). The USGS, as part of a cooperative program with the FGS, published a statewide map recognizing four geological settings associated with predominant sinkhole types in Florida as follows (Sinclair and Stewart 1985): (1) gradual development of solution sinkholes dominate; (2) cover-subsidence sinkholes dominate; (3) numerous abrupt cover-collapse sinkholes dominate; (4) deep cover-collapse sinkholes dominate. The areas delineated by Sinclair and Stewart (1985) are not aligned with sinkhole observations in more recent years, but do provide valuable data on the predominant sinkhole types. A database of sinkholes was first published by the FGS (Spencer and Lane 1995) and called "Florida Sinkhole Index". This original database was compiled from a voluntary public reporting mechanism and not all sinkholes were assessed by a professional geologist, and thus included non-karst-related sinkholes. The FGS abandoned the name "Florida Sinkhole Index", and having renamed it, now maintains a database of "Subsidence Incidence Reports." Additionally, the FGS has an online form (FGS 2012b) for citizens to report subsidence incidents and currently maintains an online database of these reports with a disclaimer indicating that many of these incidents are not field checked by a qualified geologist or engineer. In 2013, the FGS received $\$ 1.1$ million to develop a scientifically defensible sinkhole vulnerability map and develop new standards for sinkhole-vulnerability studies (FLDEP Press Office 2013; Kromhout and Baker 2014; Witze 2013). The FGS provides a graphic user interface named Map Direct for the subsidence incidence database and multiple karst or karst-related features such as swallets (sinking streams), springs, springs protection areas, and other spatial datasets (FGS 2015).

In 1990, the Florida Legislature discontinued funding to the Florida Sinkhole Research Institute and transferred these responsibilities to the FGS, which has a public webpage 
devoted to frequently asked questions of which the first 26 relate to sinkholes (FGS 2012c).

The Illinois State Geological Survey has produced a guidebook on the Illinois sinkhole plain, a classic karst terrain of the Midwest (Panno et al. 2011), and has a sinkhole area map available online. The Indiana Geological Survey (IGS) makes several karst datasets available through a public Geographic Information System Portal, IndianaMAP (2015), including sinkhole areas and points (IGS 2015). Cave density, the number of mapped cave entrances per square kilometer, is also available.

Iowa's Department of Natural Resources (Iowa DNR) maintains a dataset of current and historic sinkholes through the Iowa State University GIS Support and Research Facility (Iowa DNR 2015). The dataset includes current and historic mapped sinkholes and depressions in the form of a point dataset and a polygon dataset, indicating the boundary of the sinkhole if this boundary could be delineated with Lidar (light detection and ranging) data. These data are used by the Iowa Department of Natural Resources for enforcement of the Iowa Administrative Code, which prohibits new confined animal feeding operations (CAFOs) or expansion of existing CAFOs from constructing earthen basins for manure storage in karst terrain. The regulation of land use and construction is defined by local or state government and thus the Iowa Administrative Code applies only to Iowa.

The Kentucky Geological Survey (KGS) maintains an online sinkhole dataset (KGS 2015a) and a webpage with valuable resources about karst (KGS 2015b) with links to specific information on sinkhole flooding and cover-collapse sinkholes, and vulnerability to pollution. Additionally, the KGS has online forms available for the public to report covercollapse sinkholes (KGS 1997). Within the Maryland Department of Natural Resources, the Maryland Geological Survey (MDGS) maintains a website with information to assist the public if a sinkhole or suspected sinkhole occurs (MDGS 2015). The website provides a link to online karst maps, which can be used to determine if the suspected sinkhole is in a karst area in western Maryland and then which state or local agencies can provide technical assistance.

The Minnesota Department of Natural Resources (MNDNR) maintains an online karst feature inventory points of springs, sinks, and sinkholes (MNDNR 2015). The database description was published in Gao et al. (2002). The Missouri Geological Survey (MOGS) has a program for documenting sinkholes and has verified 15,981 sinkholes in Missouri (MOGS 2015). The USGS developed a fact sheet to help explain the catastrophic collapse sinkholes that can form in the karst terrain of Missouri (Kaufmann 2007).

The Ohio Geological Survey (OGS) has a geologic hazards program with karst mapping resources for the public. Within this program is a website for reporting sinkholes, caverns, or other karst features (OGS 2015a). The fill-in form is used to support the OGS in mapping karst features across Ohio. Additionally, the OGS has published a map of karst areas within Ohio (OGS 1999) and has produced other publications on Ohio's karst geology website (OGS 2015b). The Pennsylvania Geological Survey (PGS) provides the public with online access to an interactive map of known sinkholes in south-central and southeastern Pennsylvania (PGS 2015). The website also provides links to technical reports describing the karst features and sinkholes located in these areas.

The Tennessee Geological Survey does not maintain a website specifically for geologic hazards or sinkholes, but does provide a public education publication devoted to the topic of subsidence and sinkholes in eastern Tennessee (Kohl 2001) and a geologic hazards map of Tennessee that includes sinkhole collapse and setting (Miller 1977). Additionally a report on sinkhole collapse in Montgomery County provides some criteria needed to identify sinkholes that are likely to collapse (Kemmerly 1980). A table and map of sinkholes with depths greater than $100 \mathrm{ft}(30.5 \mathrm{~m})$ in Tennessee is available online from a website maintained by Dunigan (2015). This website indicates that over 54,000 sinkholes are visible on USGS topographic quadrangle maps and shows images of sinkhole density. These online data for sinkholes and caves are provided by the Tennessee Cave Society and references a study by Shofner et al. (2001) that provides documentation on the development of the data and links to various sinkhole density map realizations for Tennessee.

The State of Texas does not maintain a database of sinkholes; however, the Bureau of Economic Geology has done research into collapse risk in evaporite sinkhole-prone areas (Paine et al. 2012) and a current program entitled "Field Validation of Geologic Assessment of Features Sensitive to Pollution in Karst and Development of Best Management Practices," specifically mentions conducting research on infiltration at sinkholes, but does not include mapping of sinkholes or sinkhole density within the state (Hovorka et al. 2005). The only statewide database that includes any karst features is a compilation of historical data at 2,000 springs in Texas (Heitmuller and Williams 2006).

\section{Summary}

Subsidence from sudden sinkhole collapse is a geologic hazard in karst areas of the United States resulting in estimated economic losses of more than $\$ 300$ million dollars a year. States with the greatest amount of karst sinkhole damage are Florida, Texas, Alabama, Missouri, Kentucky, Tennessee, and Pennsylvania. Aside from economic damage associated with sudden sinkhole collapse, the environmental problems related to karst sinkholes are substantial owing to the increased vulnerability of groundwater from rapid infiltration of surface 
water through sinkholes. The transfer of anthropogenic contaminants resulting in water-quality degradation near sinkholes is well understood such that aquifer vulnerability assessments in karst terrain generally include geospatial analysis of sinkhole distribution (Arthur et al. 2007; Lindsey et al. 2010).

Sinkholes in karst terrain occur naturally and from anthropogenic activity. In Florida, increased rates of sinkhole formation correspond to the increase in groundwater development, drilling, surface loading, urban expansion into previously undeveloped sinkhole-prone areas and drought or precipitation extremes (Wilson and Shock 1996; Tihansky 1999).

At the national scale, the available public resources include maps of karst areas and their associated engineering aspects (Davies and LeGrand 1972; Davies et al. 1984) made digitally available by Tobin and Weary (2004). Additionally, the USGS provides a digital version of updated maps showing areas of soluble rocks based primarily on updated state geologic maps of rock units containing substantial amounts of carbonate or evaporite minerals (Weary and Doctor 2014). The digital map data were compiled from a series of integrated geologic map databases for the US produced by the USGS Mineral Resources Program (USGS 2014). More detailed geologic mapping is available from most state agencies. There is no national sinkhole hazards program or national sinkhole database.

Not all states with karst terrain and sinkhole risk have resources for the public. Most states with substantial damage attributed to karst sinkholes have public resources documenting the locations of sinkholes and/or sinkhole density, with the exception of Texas. Florida, the state with the greatest sinkhole damage in 2013, provided $\$ 1.1$ million in funding to the Florida Geological Survey for developing a scientifically defensible sinkhole vulnerability map and new standards for sinkhole-vulnerability studies (FLDEP Press Office 2013; Kromhout and Baker 2014; Witze 2013).

\begin{abstract}
Acknowledgements Reviews by Michael Lewis, Michael Bradley, and Allan K. Clark of the US Geological Survey prior to submission to $H y$ drogeology Journal improved the manuscript. Peer reviews were conducted for Hydrogeology Journal by Jonathan Arthur (state geologist, Florida Geological Survey) and Greg Stanton (US Geological Survey); both provided valuable criticism and information that greatly improved this paper. Devin Galloway (US Geological Survey and associate editor for Hydrogeology Journal) provided additional constructive feedback.
\end{abstract}

Open Access This article is distributed under the terms of the Creative Commons Attribution 4.0 International License (http:// creativecommons.org/licenses/by/4.0/), which permits unrestricted use, distribution, and reproduction in any medium, provided you give appropriate credit to the original author(s) and the source, provide a link to the Creative Commons license, and indicate if changes were made.

\section{References}

Alpha, TP, Galloway JP, Tinsley III, JC (1997) Karst topography: teacher's guide and paper model. US Geol Surv Open-File Rep 97-536A. http://geomaps.wr.usgs.gov/parks/cave/karst.html. Accessed March 2015

Arthur JD, Wood HAR, Baker AE, Cichon JR, Raines GL (2007) Development and implementation of a Bayesian-based aquifer vulnerability assessment in Florida. Nat Resour Res 16(2):93-107. doi: 10.1007/s11053-007-9038-5

Beck BF (ed) (1984) Proceedings of the First Multidisciplinary Conference on Sinkholes and the Engineering and Environmental Impacts of Karst, Orlando, Florida, October 15-17, 1984. Balkema, Leiden, The Netherlands

Beck BF (ed) (1989) Proceedings of the Third Multidisciplinary Conference on Sinkholes and the Engineering and Environmental Impacts of Karst, St. Petersburg Beach, Florida, October 2-4, 1989. Balkema, Leiden, The Netherlands

Beck BF (ed) (1993) Proceedings of the Fourth Multidisciplinary Conference on Sinkholes and the Engineering and Environmental Impacts of Karst, Panama City, Florida, January 25-27, 1993. Balkema, Leiden, The Netherlands

Beck BF (ed) (2003) Proceedings of the Ninth Multidisciplinary Conference on Sinkholes and the Engineering and Environmental Impacts of Karst, Huntsville, Alabama, September 6-10, 2003, American Society of Civil Engineers, Washington, DC

Beck BF (ed) (2005) Proceedings of the Tenth Multidisciplinary Conference on Sinkholes and the Engineering and Environmental Impacts of Karst, San Antonio, Texas, September 24-28, 2005, American Society of Civil Engineers, Washington, DC

Beck BF, Herring G (eds) (2001) Proceedings of the Eighth Multidisciplinary Conference on Sinkholes and the Engineering and Environmental Impacts of Karst, Louisville, Kentucky, April 1-4, 2001. Balkema, Leiden, The Netherlands

Beck BF, Pearson FM (eds) (1995) Proceedings of the Fifth Multidisciplinary Conference on Sinkholes and the Engineering and Environmental Impacts of Karst, Gatlinburg, Tennessee, April 2-5, 1995. Balkema, Leiden, The Netherlands

Beck BF, Stephenson B (1997) Proceedings of the Sixth Multidisciplinary Conference on Sinkholes and the Engineering and Environmental Impacts of Karst, Springfield, Missouri, April 6-9, 1997. Balkema, Leiden, The Netherlands

Beck BF, Wilson WL (eds) (1987) Proceedings of the Second Multidisciplinary Conference on Sinkholes and the Engineering and Environmental Impacts of Karst, Orlando, Florida, February 9-11, 1987. Balkema, Leiden, The Netherlands

Beck BF, Pettit AJ, Herring G (eds) (1999) Proceedings of the Seventh Multidisciplinary Conference on Sinkholes and the Engineering and Environmental Impacts of Karst, Harrisburg-Hershey, Pennsylvania, April 10-14, 1999. Balkema, Leiden, The Netherlands

Bögli A (1980) Karst hydrology and physical speleology (translated from the German by June C. Schmid). Springer, New York

Colorado Division of Homeland Security and Emergency Management (2013) State of Colorado Natural Hazards Mitigation Plan. http:// www.dhsem.state.co.us/emergency-management/mitigationrecovery/mitigation/state-colorado-natural-hazards-mitigation-plan. Accessed April 2015

Davies WE, LeGrand HE (1972) Karst of the United States. In: Herak M, Stringfield VT (eds) Karst: important Karst regions of the northern hemisphere. Elsevier, New York

Davies WE, Simpson JH, Ohlmacher GC, Kirk WS, Newton EG (1984) Engineering aspects of Karst. National Atlas of the United States of America, scale 1:7,500,000, 1 plate, US Geological Survey, Reston, VA 
Dreybrodt W (1988) Processes in Karst systems: physics, chemistry and geology. Springer Series in Physical Environment. Springer, New York

Dunigan T (2015) Tennessee sinkholes. http://tnlandforms.us/landforms/ sinks.php. Accessed August 5, 2015

Dunrud CR, Nevins BB (1981) Solution mining and subsidence in evaporite rocks in the United States. US Geol Surv Miscel Invest Ser Map I-1298, 2 sheets, scale 1:5,000,000

Ebersole S, Tavis A (2010) Sinkholes and sinkhole density across Alabama. Geological Survey of Alabama, Tuscaloosa, AL, 1 sheet

Federal Emergency Management Agency (1997) Multi-hazard identification and risk assessment: a cornerstone of the national mitigation strategy. Federal Emergency Management Agency, Washington, DC, 365 pp. https://www.fema.gov/media-library/assets/ documents/7251. Accessed October 2015

FGS (2012a) Sinkhole. http://www.dep.state.fl.us/geology/ geologictopics/sinkhole.htm. Accessed March 2015

FGS (2012b) Subsidence incident report form. http://www.dep.state.fl.us/ geology/contactus/feedback/SubsidenceIncidentReportForm_0809-2012.pdf. Accessed March 2015

FGS (2012c) Sinkholes: frequently asked questions. http://www.dep. state.fl.us/geology/contactus/faq.htm. Accessed March 2015

FGS (2015) Map direct galleries. http://ca.dep.state.fl.us/mapdirect/ gateway.jsp. Accessed October 2015

Florida Department of Environmental Protection (2013) Florida Geological Survey begins sinkhole vulnerability study following stakeholder meeting. FLDEP Bulletin 949c85. http://content. govdelivery.com/accounts/FLDEP/bulletins/949c85. Accessed August 8, 2015

Florida Office of Insurance Regulation (OIR) (2010) Report on review of the 2010 sinkhole data call (OIR report). 33 pp. http://www.floir. com/siteDocuments/Sinkholes/2010_Sinkhole_Data_Call_Report. pdf. Accessed September 30, 2015

Ford DC, Williams P (1989) Karst geomorphology and hydrology. Hyman, Winchester, MA

Ford DC, Williams P (2007) Karst hydrogeology and geomorphology. Wiley, Chichester, UK

Gao YE, Alexander C Jr, Tipping RG (2002) The development of a karst feature database for southeastern Minnesota. J Cave Karst Stud 64(1):51-57

Geological Survey of Alabama (2015) Sinkholes in Alabama. http:/gsa. state.al.us/gsa/geologichazards/Sinkholes_AL.htm. Accessed March 2015

Heitmuller FT, Williams IP (2006) Compilation of historical waterquality data for selected springs in Texas, by ecoregion. US Geol Surv Data Ser 230

Hovorka SD, Lindley A, Barrett M (2005) Field validation of geologic assessment of features sensitive to pollution in Karst and development of best management practices. http://www.beg.utexas.edu/ environqlty/grndwater/assessment_pollution.htm. Accessed August 7,2015

IGS (2015) IndianaMAP Hydrology $>>$ Karst. http://maps.indiana.edu/ layerGallery.html?category=Karst. Accessed March 2015

IndianaMAP (2015) Welcome to IndianaMap. http://www.indianamap. org. Accessed 1 March 2015

Iowa DNR (2015) Natural Resources Geographic Information Systems Library. https://programs.iowadnr.gov/nrgislibx/. Accessed September 2015

Jakucs L (1977) Morphogenetics of karst regions: variants of karst evolution (translated from the Hungarian). Wiley, New York, $284 \mathrm{pp}$

Jennings JN (1985) Karst geomorphology (revised and expanded edition of Jennings, 1971). Blackwell, Oxford, UK, 293 pp

Johnson KS (2007) Evaporite-karst problems and studies in the U.S.A. Environ Geol 53(5):937-943. doi:10.1007/s00254-007-0716-8

Kaufmann JE (2007) Sinkholes. US Geol Surv Fact Sheet 2007-3060
Kemmerly PR (1980) Sinkhole collapse in Montgomery County, Tennessee. Tennessee Geological Survey report, Tennessee Department of Environment and Conservation, Nashville, TN, 42 $\mathrm{pp}$

KGS (1997) Cover-collapse sinkhole reporting form. http://kgs.uky.edu/ kgsweb/kgsweb/sinkhole.asp. Accessed March 2015

KGS (2015a) Download sinkhole data by county. http://www.uky.edu/ KGS/gis/sinkpick.htm. Accessed March 2015

KGS (2015b) Karst land in Kentucky. http://www.uky.edu/KGS/water/ general/karst/. Accessed March 2015

Klimchouk AB (2007) Hypogene speleogenesis: hydrogeological and morphogenetic perspective. Special paper no. 1, National Cave and Karst Research Institute, Carlsbad, NM, 106 pp

Klimchouk AB, Ford DC, Palmer AN, Dreybrodt W (eds) (2000) Speleogenesis evolution of Karst aquifers. National Speleological Society, Huntsville, AL, $527 \mathrm{pp}$

Kohl MS (2001) Subsidence and sinkholes in East Tennessee: a field guide to holes in the ground. Division of Geology Public Information Series no. 1, State of Tennessee Department of Environment and Conservation, Nashville, TN, $14 \mathrm{pp}$

Kromhout C, Baker AE (2014) Perils of a dissolving state. In: Kuniansky EL, Spangler LE (eds) United States Geological Survey Karst Interest Group Proceedings: Carlsbad, New Mexico. US Geol Surv Sci Invest Rep 2014-5035, 68 pp

LandL, Doctor DH, Stephenson JB (eds) (2013) Sinkholes and the engineering and environmental impacts of Karst: Proceedings of the Thirteenth Multidisciplinary Conference, Carlsbad, NM, May 6 10 2013, NCKRI Symposium 2. National Cave and Karst Research Institute, Carlsbad, NM. http://www.karstportal.org/sites/ karstportal.org/files/KIP-0011735-25.pdf. Accessed March 2015

Lindsey BD, Katz BG, Berndt MP, Ardis AF, Skach KA (2010) Relations between sinkhole density and anthropogenic contaminants in selected carbonate aquifers in the eastern United States. Environ Earth Sci 60(5):1073-1090. doi:10.1007/s12665-009-0252-9

Lowe DJ (1992) A historical review of concepts of speleogenesis. Cave Sci 19(3):63-90

MDGS (2015) Sinkhole resources. http://www.mgs.md.gov/geology/ geohazards/sinkhole_resources.html. Accessed September 2015

Miller RA (1977) Geologic hazards map of Tennessee. Tennessee Geological Survey Map 1 sheet, Tennessee Department of Environment and Conservation, Nashville, TN

MNDNR (2015) Karst feature inventory points. https://gisdata.mn.gov/ dataset/geos-karst-feature-inventory-pts. Accessed September 2015

MOGS (2015) Sinkholes in Missouri. http:/dnr.mo.gov/geology/geosrv/ envgeo/sinkholes.htm. Accessed March 2015

NCKRI (2015) The National Karst map. http://www.nckri.org/map/links/ states.htm. Accessed August 10, 2015

OGS (1999) Ohio Karst areas. http://geosurvey.ohiodnr.gov/portals/ geosurvey/PDFs/karst/karstmap.pdf. Accessed September 2015

OGS (2015a) Sinkhole, cavern, or cave Karst reporting. http://geosurvey. ohiodnr.gov/geologic-hazards/karst-geology/report-a-sinkhole. Accessed September 2015

OGS (2015b) Sinkholes and Karst geology in Ohio. http://geosurvey. ohiodnr.gov/geologic-hazards/karst-geology/karst-mapping. Accessed September 2015

Paine JG, Buckley SM, Collins EW, Wilson CR (2012) Assessing collapse risk in evaporite sinkhole-prone areas using microgravimetry and radar interferometry. J Environ Eng Geophys 17(2):75-87

Palmer AN (1991) Origin and morphology of limestone caves. Geol Soc Am Bull 103(1):1-21

Palmer AN (2000) Hydrogeologic control of cave patterns. In: Klimchouk AB (ed) Speleogenesis: evolution of Karst aquifers. National Speleological Society, Huntsville, AL

Palmer AN, Palmer MV (eds) (2009) Caves and Karst of the U.S.A.: a guide to the significant cave and Karst areas of the United States of America. National Speleological Society, Huntsville, AL 
Palmer AN, Palmer, MV (2011) Paleokarst of the U.S.A.: a brief review. In: Kuniansky EL (ed) US Geological Survey Karst Interest Group Proceedings, Fayetteville, Arkansas, April 26-29, 2011. US Geol Surv Sci Invest Rep 2011-5031

Panno SV, Hackley KC, Kelly WR, Luman DE (2011) Guidebook 39, Illinois sinkhole plain: classic Karst terrain of the Midwestern United States. Geological Field Trip Guidebook for the 12th Multidisciplinary Conference on Sinkholes and the Engineering and Environmental Impacts of Karst, January 10-14, 2011, St. Louis, Missouri, USA, 45 pp. http://www.isgs.uiuc.edu/nsdihome/ outmeta/IL_Sinkhole_Areas_Py.html Accessed. Accessed August 2015

PGS (2015) Sinkholes in Pennsylvania. http://www.denr.state.pa.us/ topogeo/hazards/sinkholes/. Accessed March 2015

Robertson J, Orndorff RL (2013) The science of sinkholes. http://www. usgs.gov/blogs/features/usgs_top_story/the-science-of-sinkholes/. Accessed March 2015

Rupert F, Spencer S (2004) Florida's sinkholes. Florida Geological Survey Poster no. 11, FGS, Tallahassee, FL

Schmidt W (2005) Geological and geotechnical investigation procedures for evaluation of the causes of subsidence damage in Florida. Florida Geological Survey Spec. Pub. 57, FGS, Tallahassee, FL, 22 pp

Shaw TR (1992) History of cave science: the exploration and study of limestone caves, to 1900, 2nd edn. Sydney Speleological Society, Sydney

Shofner GA, Mills HH, Duke JE (2001) A sample map index of karstification and its relationship to sinkhole and cave distribution in Tennessee. J Cave Karst Stud 63(2):67-75

Sinclair WC, Stewart JW (1985) Sinkhole type, development, and distribution in Florida. US Geol Surv Map Ser 110, 1 plate. http://dep. state.fl.us/geology/geologictopics/sinkhole/sinkholedevelopment. htm. Accessed March 2015

Soller DR, Packard PH, Garrity CP (2012) Database for US Geological Survey Map I-1970, Map showing the thickness and character of quaternary sediments in the glaciated United States east of the Rocky Mountains. US Geological Survey Data Series 656. http:// pubs.usgs.gov/ds/656/. Accessed June 2014

Spencer S, Lane E (1995) Florida sinkhole index: Tallahassee, Florida. Florida Geol Surv Open-File Rep 58. http://aquaticcommons.org/ 729. Accessed March 2015

Sweeting MM (1973) Karst landforms. Columbia University Press, New York

The Florida Senate (2010) Issues relating to sinkhole insurance. Interim report 2011-104, December 2010, Committee on Banking and Insurance, Tallahassee, FL, 47 pp. http://www.flsenate.gov/ UserContent/Session/2011/Publications/InterimReports/pdf/2011104bi.pdf. Accessed August 8, 2015

Tihansky AB (1999) Sinkholes, west-central Florida. In: Galloway D, Jones DR, Ingebritsen SE (eds) Land subsidence in the United States. US Geol Surv Circ 1182, pp 121-140

Tobin BD, Weary DJ (2004) Digital engineering aspects of karst map: a GIS version of Davies, W.E., Simpson, J.H., Ohlmacher, G.C., Kirk, W.S., and Newton, E.G., 1984, Engineering aspects of Karst-US Geological Survey, National Atlas of the United States of America, scale 1:7,500,000. US Geol Surv Open-File Rep 2004-1352. http:// pubs.usgs.gov/of/2004/1352/. Accessed March 2015
Trudgill S (1985) Limestone geomorphology. Geomorphology Text no. 8. Longman, London

US Environmental Protection Agency (2013) Level III and IV ecoregions of the continental United States. Office of Research and Development, National Health and Environmental Effects Research Laboratory, Washington DC. http://www.epa.gov/wed/ pages/ecoregions/level iii iv.htm. Accessed June 2014

USA (2015) The home of the U.S. Government's open data. http://www. data.gov. Accessed October 2015

USGS (2014) Mineral resources online spatial data: digital geologic maps of the US states with consistent lithology, age, GIS database structure, and format. http://mrdata.usgs.gov/geology/state/. Accessed May 16, 2014

USGS (2015a) National Cooperative Mapping Program. http://ncgmp. usgs.gov/. Accessed March 2015

USGS (2015b) Sinkholes. The USGS Water Science School, USGS, Reston, VA. http://water.usgs.gov/edu/sinkholes.html. Accessed March 2015

USGS (2015c) USGS ScienceBase-Catalog. https://www.sciencebase. gov/catalog/. Accessed October 2015

Veni G (2002) Revising the Karst map of the United States. J Cave Karst Stud 64(1):45-50

Waltham T, Bell FG, Culshaw M (2005) Sinkholes and subsidence: Karst and cavernous rocks in engineering and construction. Springer-Praxis Books in Geophysical Sciences, Springer, Heidelberg, Germany

Watson RA, White WB (1985) The history of American theories of cave origin. Geol Soc Am Cent Spec 1:109-123

Weary DJ, Doctor DH (2014) Karst in the United States: a digital map compilation and database. US Geol Surv Open File Rep 2014-1156. doi:10.3133/ofr20141156

White WB (1988) Geomorphology and hydrology of Karst terrains. Oxford University Press, New York

White JL (2012) Colorado map of potential evaporite dissolution and evaporite Karst subsidence hazards. Colorado Geological Survey, Golden, CO. http://coloradogeologicalsurvey.org/publications/ online-publications/colorado-map-of-potential-evaporitedissolution-and-evaporite-karst-subsidence-hazards/. Accessed March 2015

Williams LJ, Kuniansky EL (2015) Revised hydrogeologic framework of the Floridan aquifer system in Florida and parts of Georgia, Alabama, and South Carolina. US Geol Surv Prof Pap 1807. doi: $10.3133 / \mathrm{pp} 1807$

Wilson WL, Shock EJ (1996) New sinkhole data spreadsheet manual (v1.1). Subsurface Evaluations, Winter Springs, FL

Witze A (2013) Florida forecasts sinkhole burden. Nature 504:7479. http://www.nature.com/news/florida-forecasts-sinkhole-burden-1. 14337. Accessed August 8, 2015

Yuhr LB, Alexander C, Beck BF (eds) (2008) Proceedings of the Eleventh Multidisciplinary Conference on Sinkholes and the Engineering and Environmental Impacts of Karst, Tallahassee, FL, September 22-26, 2008. American Society of Civil Engineers, Washington, DC. doi:10.1061/9780784410035

Yuhr LB, Kaufmann JA, LaMoreaux JW (eds) (2011) Proceedings of the Twelfth Multidisciplinary Conference on Sinkholes and the Engineering and Environmental Impacts of Karst, St. Louis, Missouri, January 10-14, 2011. USGS, Reston, VA. http://link. springer.com/journal/13146/28/1/page/1. Accessed March 2015 